\title{
Correction to: Development of typological classification and its relationship to microdifferentiation in ethnic India
}

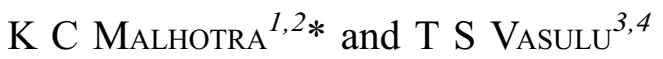 \\ ${ }^{1}$ Formerly Professor of Anthropology \& Human Genetics, Indian Statistical Institute, Kolkata, India \\ ${ }^{2}$ Present Address: 1385, Church View Enclave, Sector 29, Noida 201 301, India \\ ${ }^{3}$ Retired Professor of Anthropology \& Human Genetics, Indian Statistical Institute, Kolkata, India \\ ${ }^{4}$ Present Address: 5, RM Banerjee Road, Bon Hoogly, Baranagar, Kolkata 700108, India \\ *Corresponding author (Email, kcmalhotra2001@hotmail.com)
}

Published online 14 August 2019

\section{Correction to: $J$ Biosci (2019) 44:64}

https://doi.org/10.1007/s12038-019-9880-8

In the July 2019 issue of the Journal of Biosciences, in the article titled "Development of typological classification and its relationship to microdifferentiation in ethnic India” by K C Malhotra and T S Vasulu (DOI: 10.1007/s12038-019-9880-8; volume 44, article 64), the affiliations of $\mathrm{T} S$ Vasulu have been wrongly mentioned as:

${ }^{3}$ Formerly Associate Professor of Anthropology \& Human Genetics, Indian Statistical Institute, Kolkata, India

${ }^{4}$ Present Address: 25, RM Banerjee Road, Bon Hoogly, Baranagar, Kolkata 700108, India

The correct affiliations should read as:

${ }^{3}$ Retired Professor of Anthropology \& Human Genetics, Indian Statistical Institute, Kolkata, India

${ }^{4}$ Present Address: 5, RM Banerjee Road, Bon Hoogly, Baranagar, Kolkata 700108, India 